\title{
NOSTALGIA, SENSATIONS AND LOCAL PRODUCTS IN RURAL TOURISM EXPERIENCES IN A PORTUGUESE SCHIST VILLAGE
}

\author{
Elisabeth Kastenholz ${ }^{1}$, Pilar Fernández-Ferrín², Áurea Rodrigues ${ }^{3}$
}

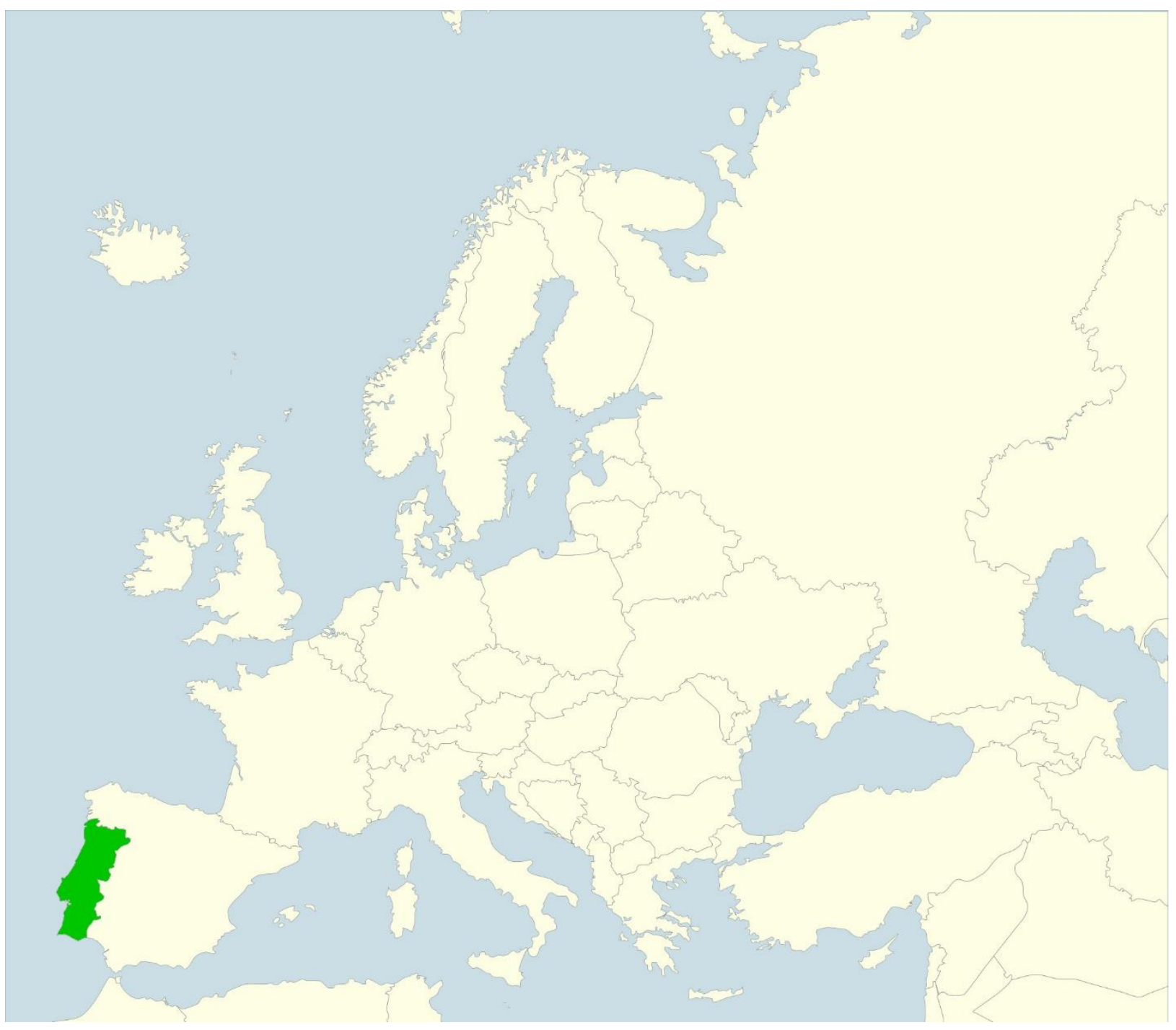

\footnotetext{
${ }^{1}$ Elisabeth Kastenholz (corresponding author), Associate Professor at Universidade de Aveiro, Departamento de Economia, Gestão, Engenharia Industrial e Turismo, Research Unit Governance, Competitveness and Public Policies; email: elisabethk@ua.pt; ORCID: 0000-0003-4700-0326.

2 Pilar Fernández-Ferrín, Associate Professor at the University of the Basque Country, Faculty of Economy and Business, Vitoria-Gasteiz (Spain); email: pilar.fernandezf@ehu.eus: ORCID: 0000-0002-7507-2047.

3 Áurea Rodrigues, Assistant Professor at the University of Évora Portugal, Social Sciences School and associate researcher at CIDEHUS; email: aor@uevora.pt ORCID: 0000-0002-4989-5365.
} 
Abstract: Rural tourism has attracted increasing attention in recent decades. It responds to new market demands, some of which driven by a nostalgic quest for a 'rural idyll', as well as the need of many European rural territories to find new sources of income and development. Local products represent a relevant asset for appealing to rural tourist experiences, enhancing local identity and regional economies. Based on a study of the rural tourist experience as lived by visitors of a Portuguese schist village, the present paper analyses the role of nostalgia and sensory experiences in leading to tourists' purchase of local products, using a conditional process analysis. Results confirm this link and also show that tourists seem to be more affected by these dynamics than excursionists. Implications of results for management and development of rural territories involving tourism and sales of local products are further discussed.

Keywords: rural tourism, nostalgia, local products, tourist experience, sensory experience, Portugal

Resumo: O turismo rural tem atraído cada vez mais atenção nas últimas décadas, respondendo a novas procuras de mercado, algumas das quais impulsionadas por uma busca nostálgica de um 'ideal rural', bem como pela necessidade que muitos territórios rurais Europeus têm de encontrar novas fontes de rendimento e desenvolvimento. Os produtos locais representam um ativo relevante para experiências atrativas de turismo rural, valorizando a identidade local e as economias regionais. A partir de um estudo da experiência turística rural vivida por visitantes de uma Aldeia do Xisto Portuguesa, o presente artigo analisa o papel da nostalgia e das experiências sensoriais na promoção da compra turística de produtos locais, utilizando uma análise de processo condicional. Os resultados confirmam essa ligação e também mostram que os turistas parecem ser mais afetados por essa dinâmica do que os excursionistas. Apresentase também uma discussão sobre as implicações dos resultados para a gestão e desenvolvimento dos territórios rurais, envolvendo turismo e vendas de produtos locais.

Palavras chave: turismo rural, nostalgia, produtos locais, experiencia turística, experiencia sensorial, excursionismo, Portugal

Zusammenfassung: Der ländliche Tourismus hat in den letzten Jahrzehnten zunehmend Aufmerksamkeit auf sich gezogen und auf neue Marktanforderungen reagiert, von denen einige auf die nostalgische Suche nach einer „ändlichen Idylle“ sowie auf die Notwendigkeit vieler europäischer ländlicher Gebiete zurückzuführen sind, neue Einkommens- und Entwicklungspotentiale zu finden. Lokale Produkte sind ein wichtiges Kapital für ansprechende Erlebnisse auf dem Lande, aber auch für die Stärkung lokaler Identität und regionaler Wirtschaft. Basierend auf einer Studie über das Reiseerlebnis auf dem Land, aus der Sicht der Besucher eines portugiesischen Schieferdorfes, analysiert der vorliegende Artikel die Rolle von Nostalgie und sensorischen Erfahrungen beim Kauf lokaler Produkte durch Touristen unter Verwendung einer bedingten Prozessanalyse. Die Ergebnisse bestätigen den erwarteten Zusammenhang und zeigen auch, dass Touristen von dieser Dynamik stärker betroffen zu sein scheinen als Ausflügler. Die Auswirkungen der Ergebnisse auf das Management und die Entwicklung ländlicher Gebiete, einschließlich Tourismus und Verkauf lokaler Produkte, werden weiter erörtert.

Schlüsselwörter: ländlicher Tourismus, Nostalgie, lokale Produktes, Reiseerlebnis, sensoriales Erlebnis, Ausflugsreisen, Portugal 
Resumen: El turismo rural ha atraído una atención creciente en las últimas décadas, respondiendo a las nuevas demandas del mercado, algunas de ellas impulsadas por la búsqueda nostálgica de un "idilio rural", así como por la necesidad de muchos territorios rurales europeos de encontrar nuevas fuentes de ingresos y desarrollo. Los productos locales representan un activo importante para atraer experiencias turísticas rurales, mejorar la identidad local y las economías regionales. A partir de un estudio de la experiencia turística rural vivida por los visitantes de una aldea portuguesa de pizarra, el presente trabajo analiza el papel de la nostalgia y las experiencias sensoriales en la compra de productos locales por parte de los turistas, utilizando un análisis de proceso condicional. Los resultados confirman este vínculo y también muestran que los turistas parecen estar más afectados por estas dinámicas que los excursionistas. Se discuten además las implicaciones de los resultados para la gestión y el desarrollo de los territorios rurales, en relación con el turismo y la venta de productos locales.

Palabras clave: turismo rural, nostalgia, productos locales, experiencia turística, experiencia sensorial, excursionismo, Portugal

\section{Highlights}

- Visitors to a Portuguese village show different levels of nostalgia towards that place, (more or less) intense sensorial experiences,

- and diversity in purchasing local products.

- Nostalgia positively impacts on the purchase of local products via sensory experiences.

- This relationship holds true only for tourists, however, not for same-day visitors.

\section{Introduction}

Rural tourism is a field of activity and study that has attracted increasing attention in recent decades. It responds to new market demands, some of which driven by a nostalgic quest for a 'rural idyll', as well as the need of actors of rural territories to find new sources of income and development and thus guarantee quality of life (Lane \& Kastenholz, 2015; Vaishar, Vidovićová \& Figueiredo, 2018; Xue \& Kernstetter, 2019). However, not all rural tourism initiatives yield success nor do they contribute to sustainable rural development (Ballina, Valdés \& del Valle, 2021; Martínez-Roget, Moutela \& Rodríguez, 2020; Ribeiro \& Marques, 2002; Sharpley, 2002). Indeed, many scholars ask for improved product and destination development to create wellcoordinated, appealing and meaningful tourist experiences as well as development opportunities which make the best use of endogenous resources and competences (Lane \& Kastenholz, 2015; Kastenholz et al., 2012; Saxena et al., 2007) or 'countryside capital' (Garrod et al., 2006). For this purpose, both an understanding of a) the destination, its resources and potentialities and b) the market, its profile, behaviour, motivations and desires, is needed to reach the best possible destination-market mix (Kastenholz, 2004).

Rural tourism, although not consensual in its definition nor homogenous in its manifestations or market profile (Eusébio et al., 2017; Lane \& Kastenholz, 2015), is frequently motivated by nostalgia (Bell, 2006; Christou, Farmaki \& Evangelou, 2018; Figueiredo, Kastenholz \& Lima, 2013; Rodrigues, Kastenholz \& Morais, 2012; Vignolles \& Pitchon, 2014). Studies have also highlighted the demand for rural areas in providing sensory-rich experiences, which are mostly related to the countryside's natural environment, but also to its traditional local culture (Agapito, Pinto \& Mendes, 2017; Silkes, Cai \& Lehto, 2013; Sims, 2009). Local products are part of this particular rural tourism system, shaped by a territory where communities have learned to make the best of local resources (Kastenholz, Eusébio \& Carneiro, 2016). They are frequently also nostalgically sought, consumed and bought by travellers as signs of local culture and identity, representing the particular and unique aspects of a living space surviving the pressures of globalization, massification and standardization (Sidali et al., 2015; Sims, 2009). Interest in these 
products may thus be motivated by rural tourists' nostalgia, while effective purchase should also depend on the experience lived in the visited place, particularly its sensorial facets - sights, sounds, smells, tastes and tactile experience opportunities. This sensorial experience might stimulate the visitors' wish to intensify the place experience by purchasing local products, thereby making it tangible and prolonging it, even after the visit. Based on this rationale, in this study we tested the role of nostalgia in triggering the purchase of local products, mediated by the intensity of the sensorial destination experience. For this purpose, visitor survey data collected in the schist village of Janeiro de Cima (Portugal) was used. Also, type of tourist (excursionist versus tourist) as a potential moderator on the proposed relationship from nostalgia over sensorial experience to the purchase of local products was tested, since excursionists were found to have less intense experiences (Kastenholz, Marques \& Carneiro, 2020).

Through a literature review of rural tourist experiences, with particular emphasis on the role of nostalgia and sensory experiences within rural tourism, a research model is proposed in this article which relates nostalgia feelings through sensorial experiences to the purchase of local products, as detailed in the following sections. The empirical case selected is then presented as well as the methodology of data collection and analysis. Results are discussed next and finally implications for both theory and rural destination marketing, with avenues for further research also suggested.

\section{Theoretical background and proposed model}

\subsection{Local and traditional products in rural tourism}

The purchase of local products has been identified as a relevant and appealing tourist activity in several studies, both in the general tourism context (Hu \& Yu, 2007) and particularly in rural tourism, where such products play an outstanding role in enhancing a sense of authenticity, meaningfulness and memorability of the experience (Kastenholz, Eusébio \& Carneiro, 2016; Lima, Eusébio \& Kastenholz, 2012; Sims, 2009). In a segmentation analysis based on expenditure levels, within a rural/mountain destination context, Lima, Eusébio \& Kastenholz (2012) found a group of 'food \& shopping oriented' rural tourists, while all other segments revealed a relatively high interest in purchasing local products, confirming results from other studies (Kastenholz, Carneiro, Marques \& Lima, 2012; Skuras et al., 2006). As a matter of fact, in a time where unique experiences are increasingly sought (Tung \& Ritchie, 2011), 'traditional food and handicraft production may help in the design of more authentic or authentically perceived/lived rural tourism experiences' (Kastenholz, Eusébio \& Carneiro, 2016: 731). In this line of argument, Suhartanto et al. (2018) revealed the importance of the perception of uniqueness and authenticity of food souvenirs for tourists' satisfaction and respective behavioural intentions regarding the destination visited. As a matter of fact, local products represent distinctive endogenous resources or, in Ritchie and Crouch's (2003) terms, most important 'comparative advantages' of the territory visited. They potentially enhance the destination's 'competitive advantages' and global appeal through wise integration of these items and the associated immaterial heritage - in the overall rural tourist destination experience (Fusté-Forné, 2020), its image and meanings, as projected, shared and enriched through storytelling (Hartman, Parra \& Roo, 2019). Additionally, as di Clemente et al. (2019:1) find in their exploratory study of the international food tourism market, 'involvement and memorable food-based experiences can help the long-lasting loyalty of food tourists towards both local products and the destination'. This loyalty enhancement is also observable in results of Madaleno et al.'s (2019) study on the international tourist market in Portugal, which revealed an impact of local agro-food consumption/purchase at a destination on loyalty to that place and its products, also via souvenir purchase and recommendation to friends and relatives.

The literature about local products is very focused on food products. Although there is no universally accepted definition for these, the concept seems closely linked to geographical proximity on the one hand and social proximity on the other. With regard to geographical proximity, two criteria are usually considered. The first refers to the distance between the place of production and where that product is consumed, measured in miles (Onozaka, Nurse, \& McFadden, 2010) or kilometres (Lim \& Hu, 2016); the second refers to political-administrative 
boundaries in which both production and consumption take place, whether it is a county (Groves, 2005), a state (Darby et al., 2008), or even a country (Brown, 2003). With regard to social proximity, several studies suggest that consumers are concerned about interaction with the producer; they want to know what the production methods are or which companies are behind them (Martinez et al., 2010; Sidali et al., 2015), prioritizing products produced by small companies and with sustainability criteria (Han \& Martinez, 2010).

These two types of proximity bring value to consumers. On the one hand, geographical proximity has been associated with lower consumption of fuel and chemicals (La Trobe, 2002); on the other hand, the purchase of local products is perceived by consumers as a way to support local producers, sometimes small family businesses, favouring the local economy and employment (Lang, Stanton, \& Qu, 2014; Martínez et al., 2010; Sidali et al, 2015). In addition, local products are perceived as products with higher quality, freshness, nutritional values and better taste (Chambers at al., 2007).

Local products are often closely related to the idea of 'traditional products', although the two concepts are not equivalent. Traditional products are linked to territory and tradition (Jordan, 2000) and in most cases their production is local (Truefood, 2006), but not all local products are traditional. The results of the TRUEFOOD project indicated that European consumers perceived traditional products as those "frequently consumed or associated with specific celebrations and/or seasons, transmitted from one generation to another, made in a specific way according to gastronomic heritage, naturally processed, and distinguished and known because of its sensory properties and associated with a certain local area, region or country" (Vanhonacker et al., 2010, p. 454). The local character of the product is, in this context, perfectly complemented by its traditional character. The first will allow the product to be associated with sustainable consumption, with the proximity between production and consumption and with support for the local economy (Holcomb et al., 2016; Martínez et al., 2010); the second will make consumers relate the product to simplicity, naturalness and purity (Guerrero et al., 2009), as well as to genuine local culture, valued for its nostalgically valued 'authenticity' (Sims, 2009). Products that combine these characteristics are more valued by consumers than products that are local, but not traditional (Fernández-Ferrín et al., 2018). It can be expected that consumers will maintain these evaluations and corresponding purchase preferences when travelling, particularly when visiting rural destinations, as actually confirmed by the role attributed to local products in rural tourism (Kastenholz et al., 2012; Sidali et al., 2015; Sims, 2009).

\subsection{Nostalgia in rural tourism}

Nostalgia as a predictor of visitor motivation or consumption intention in rural tourism has received increasing recognition in the tourism literature in recent years (Chi et al., 2017; Christou, 2020; Christou, Farmaki \& Evangelou, 2018; Fairley et al., 2018; Frisvoll et al., 2016; Jarratt \& Gammon, 2016; Komppulah, 2014; Rodrigues \& Kastenholz, 2021; Yagi \& Pearce, 2018; Yeh, 2015). Nostalgia can be defined as "a positively balanced complex feeling, emotion or mood produced by reflection on things (objects, persons, experiences, ideas) associated with the past" (Holak \& Havlena, 1998: 218). Russel (2008: 104, quoting Baker \& Kennedy, 1994) refers to "a bittersweet yearning for an experience, product, or service from the past". Nostalgia can result from past personal experience, also designed as 'real nostalgia' (Russel, 2008), or may be induced by storytelling, marketing and media. Holak, Matveev and Havlena (2007) distinguish four dimensions of nostalgia, namely: a) personal nostalgia, when related to a person's past experiences; b) interpersonal nostalgia, when induced by the memories of others and the combination of the experiences of others with the individual's personal interaction with these people; c) cultural nostalgia, when originated in direct experience of a community and immersion in its culture and way of life, resulting in a common cultural identity, and d) virtual nostalgia, when evoked by an experience shared in an indirect manner such as, for example, the experience of media messages, films, music and art. Nostalgic meanings seldom arise only from the object itself and its sensorial cues (Christou et al., 2018), but are connected with an individual's experiences with people and objects at specific physical places (Holbrook \& Schindler, 2003; Kessous, 2015). Generally, rural destinations are seen as idyllic places where life happens as in the "good old days", in harmony with nature, at a slow pace, and with close, trustful social relations (Cawley 
\& Gillmor, 2008; Chi et al., 2017; Figueiredo, 2009; Kastenholz et al., 2016; Kim \& Kim, 2018). The characteristics of those places and cues such as scents, sounds, pictures, evidence of (im)material traditions within this space can act as stimulators for nostalgia (Christou et al., 2018) that can be triggered by more than an individual's past experiences, namely by a variety of external stimuli (Christou, 2020; Sedikides et al., 2015). Christou et al.'s (2018) model, developed with qualitative data from rural tourism stakeholders in Cyprus, may be extended to integrate the concept of 'the nostalgic tourist' and as a specification of the 'meta-tourist phase', through 'nostalgic memories and memorabilia', as illustrated in Figure 1.

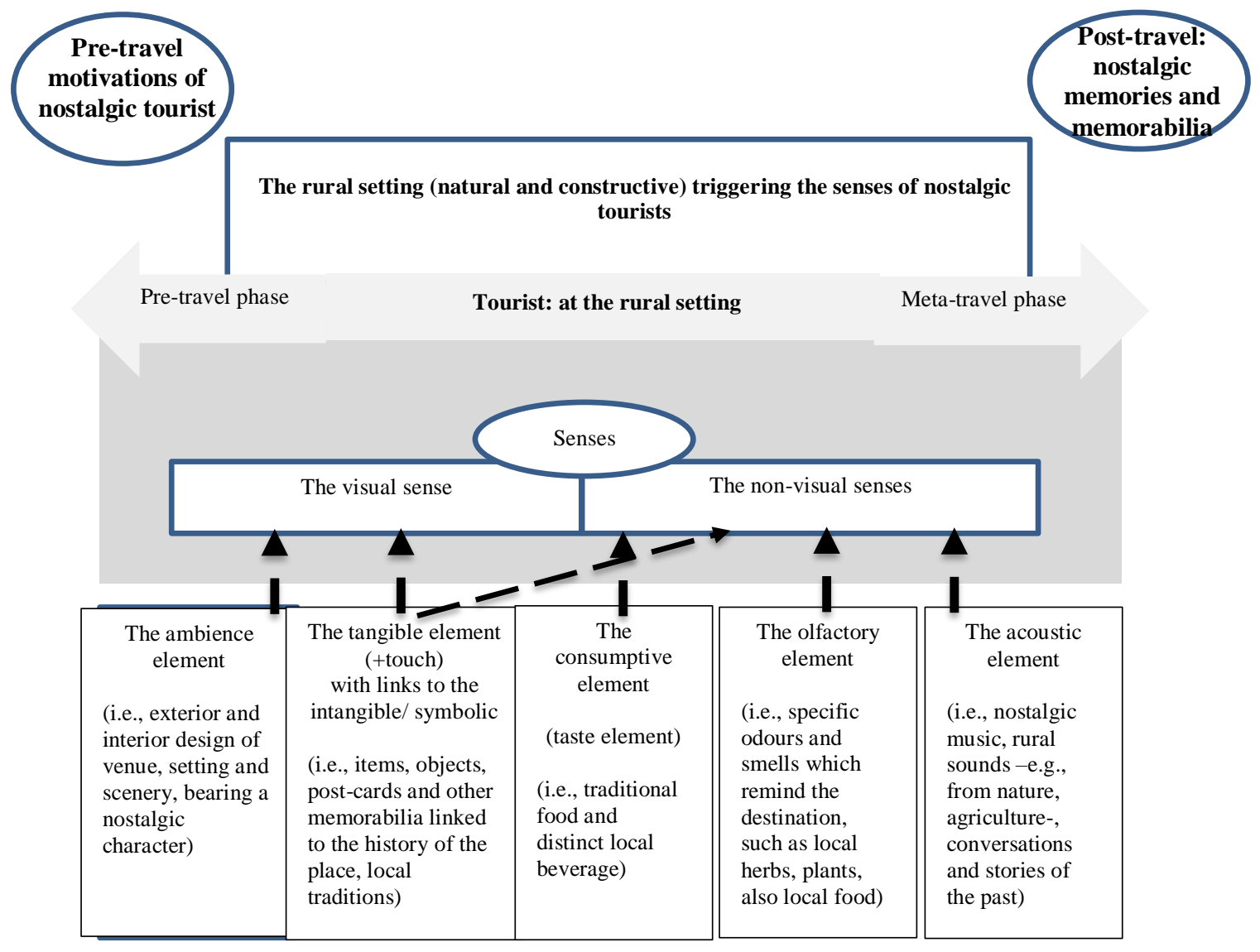

Fig 1. Adapted from Christou et al. (2018).

Russel (2008) suggests the existence of a 'nostalgic tourist segment' who search for 'authentic cultural experiences' and reveal more intense immersion in their tourist experiences. Also, in rural tourism, individuals may actively seek signs of their personal history or family roots, or the ideal of a countryside embellished through collective narrative (Cawley \& Gillmor, 2008; Figueiredo, 2009; Kastenholz \& Carneiro, 2016; Rodrigues et al., 2012). Accordingly, visitors who previously feel nostalgic for a rural place or for 'rurality' in general, due to a combination of the previously mentioned facets of nostalgia (e.g., previous experience, family background related to rural areas, media exposure), may be particularly sensitive to sensorial triggers of nostalgia at the rural place visited, leading to hypothesis 1.

$\mathrm{H} 1$ : Nostalgia positively influences sensorial experience at a rural destination.

Since local food and handicraft products are embedded in and the result of local culture and traditions, they are frequently associated with 'authenticity' and present icons of these nostalgically idealized places (Swanson \& Timothy, 2012). These products may thus also present manifestations or physical extensions of the 'rural nostalgia', permitting travellers to extend the idealized experience lived in a place and make it more tangible, share it with relevant others and remember the associated positive feelings (Wilkins, 2010) of a 'rural way of life' at home. Consequently, particularly nostalgic rural tourists should be interested in purchasing local products. 


\subsection{Local products, sensorial experience and nostalgia}

Local products are frequently purchased in rural tourism as a means of extending and sharing the highly valued 'authentic' countryside experience, lived in a particular place, with both local food and handicraft standing out as symbols of rurality and of an idealized past of specific locations and communities (Kastenholz et al., 2012; Kastenholz et al., 2016; Thompson, Hannam, \& Petrie, 2012; Wilkins, 2010).

As for local food, the literature distinguishes two main motivations for such products (FernándezFerrín et al., 2018; Merle et al., 2017): (1) private motivations or "benefits for oneself", and (2) public motivations or "benefits for others". With regard to private motivations, local products have been linked to greater freshness, taste and health, so we could say that some sensory experiences, particularly taste and smell, are closely linked to the consumption of local food and individual, functional or hedonic motivations. As far as public motivations are concerned, especially those of social and environmental nature, literature highlights the growing consumer interest in and support of unconventional, typically small-scale and more sustainable food production (Bond, Thilmany, \& Keeling Bond, 2008; Costanigro et al., 2014). These would include an interest in local products because of the opportunity to support local employment and traditions and more artisanal, yet environmentally friendly production methods, while reducing the energy resources associated with transportation.

The search for these less conventional and industrialized products and processes may be associated with a certain nostalgia for past times. This is characterized by other forms of production, in less globalized economies, with short or direct supply chains and with a greater knowledge not only of the methods used but also by the people involved in these processes (Balogh et al., 2016; Sidali et al., 2015). Nostalgic people can be expected to show a greater interest in craft processes, less elaborate ingredients, natural raw materials and, in general, everything they associate with ways of doing things similar to those of the past. This should be particularly true for nostalgic people visiting the countryside and engage with its unique endogenous resources and feel nostalgia regarding 'rurality' and an expected traditional rural way of life (Carvalho et al., 2016).

Local products with a traditional character may present higher levels of appeal for these tourists when consumed at the destination, as "consumers associate traditional products with habits and heritage passed from one generation to another (...) however, traditions cannot easily be exported, so the traditional product outside its area of influence, without the emotional attachment of past experience, is likely to be perceived as another conventional, competing product within a crowded marketplace" (Balogh et al., 2016: 182). This statement highlights the particular value added by consumption of nostalgically sought local products in the very place or region of their production. As a consequence, the following hypothesis is suggested.

H2: Nostalgia positively influences the purchase of local products.

However, sensorial experiences are also increasingly recognized as essential in enhancing the quality and memorability of tourist experiences (Carneiro et al., 2019) and should be especially relevant in the context of local food products.

Analysing consumer perceptions of traditional products in six European countries, Almli et al. (2011) found that the most valued attributes were related to the sensory dimension: (1) intrinsic attributes (taste and appearance); and (2) experience attributes (taste specialty, quality and consistency of quality). For Guerrero et al. (2009: 348), "tradition is tasteful (...) sensory parameters are one of the simplest and easiest ways to recognize and identify the authenticity of a food product". In the same vein, Keeling Bond et al. (2006) pointed out that the first motivation for purchasing products directly from the producer is related to the 'taste and flavour' dimension. Kastenholz, Eusébio \& Carneiro (2016) also showed the positive impacts of sensorial experiences reported by rural tourists in both their decision to purchase local products and the amount spent on them. This evidence supports the next hypothesis.

H3: Sensorial experience positively influences the purchase of local products. 
Since rural tourists who feel nostalgic about the countryside are suggested as being more sensitive towards sensorial stimuli resonating such feelings $(\mathrm{H} 1)$, one may also expect that these persons' desire to purchase local products, triggered by nostalgia $(\mathrm{H} 2)$, should be particularly enhanced by such sensorial experiences $(\mathrm{H} 3)$, i.e., nostalgia may lead to purchase of local products via exposure to relevant sensorial stimuli $(\mathrm{H} 4)$.

$\mathrm{H} 4$ : Sensorial experience mediates the relationship between nostalgia and the purchase of local products.

\subsection{Excursionism versus tourism}

Length of stay at a destination, particularly the distinction between a same-day visit and a more extended tourism stay, is a crucial determinant of the quality of one's experience at a rural destination (Kastenholz, Marques, \& Carneiro, 2020). It directly affects visitors' exposure to and opportunities for consuming local food and other local products (Frisvoll et al., 2016; Madaleno et al., 2019). The shorter the stay, which is typical of a same-day visit, the less time there is available to enjoy and appreciate the diverse facets of a destination and to be immersed in a place and its culture with all senses. Consequently, the experience should be less intense and more superficial, apart from naturally presenting fewer opportunities for into contact with local production, in its diverse manifestations. It is therefore logical to assume that tourists who stay longer, when motivated by nostalgia, live their travel experience in a sensory richer way, have and seek more opportunities of culturally immersive experiences and tend to purchase more local products than those coming as excursionists. This rationale leads to hypothesis 5 .

H5: Type of visit, in terms of tourism versus excursionism, reflecting length of stay and corresponding intensity of the experience, moderates the effect of nostalgia and sensorial experience on the purchase of local products. Specifically, it is suggested that nostalgic tourists tend to live sensorily richer experiences, which lead to more local product purchase, when compared to excursionists.

\subsection{The model}

Last, but not least, variables such as age (Kastenholz et al., 2016; Russel, 2008), gender (Kim et al., 2009) and previous experience with/trying local food (Madaleno et al., 2019; Skuras et al., 2006) were found to potentially affect purchase of local products. In the present study, the relationship between nostalgia, sensory experience and purchase of local products is the central focus of analysis, with excursionist versus tourist travel types considered as a moderator variable. Apart from this, the model will control for age, gender, and having previously tried local food.

Figure 2 presents all the relationships suggested in the previously mentioned hypotheses in a model of nostalgic, sensory-stimulated, local product-purchase of rural tourists. This conceptual diagram (model 15, Hayes, 2018) is a variant of a conditional process model and shows both the direct and indirect effects of nostalgia on the purchase of local products, moderated by the type of visitor. This methodology is used "when one's research goal is to describe the boundary conditions of the mechanism or mechanisms by which a variable transmits its effect on another" (Hayes). The model will be validated with data collected from visitors of a Portuguese schist village, as explained next. 


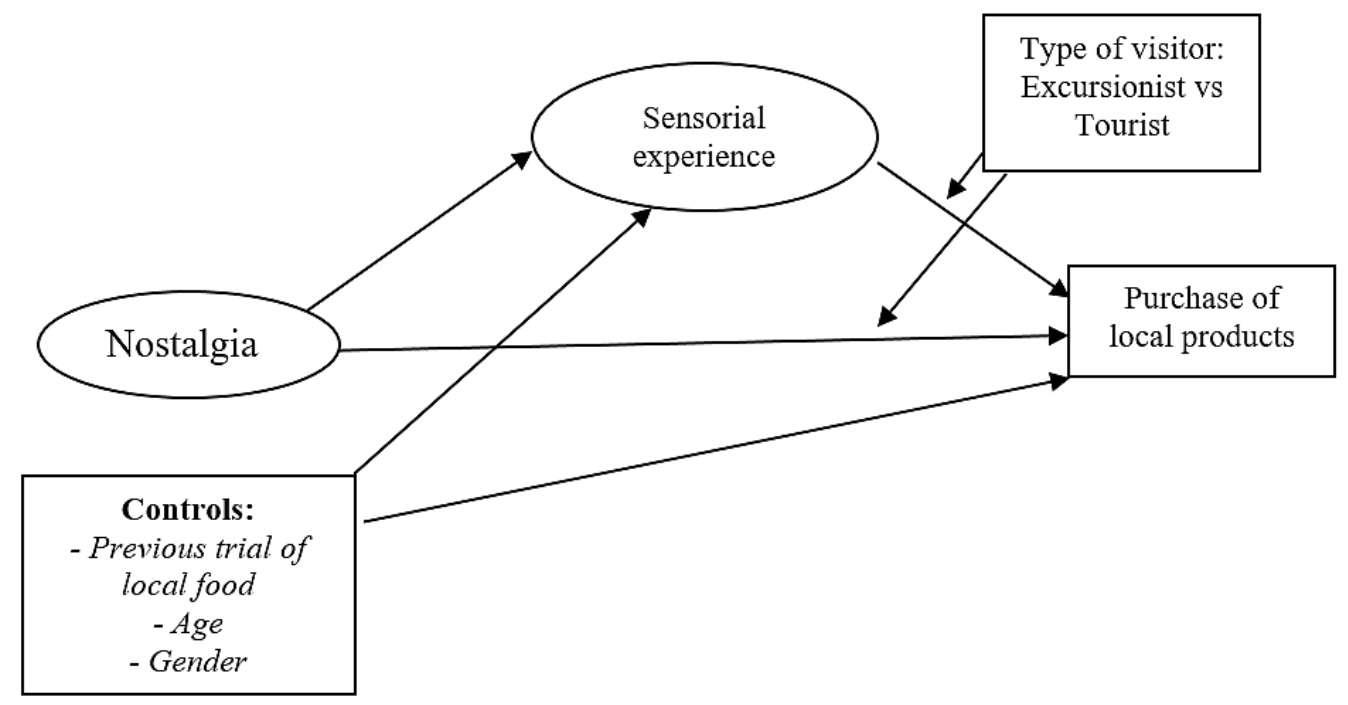

Fig 2. Theoretical model. Source: self-elaboration

\section{Methods}

\subsection{The case study village}

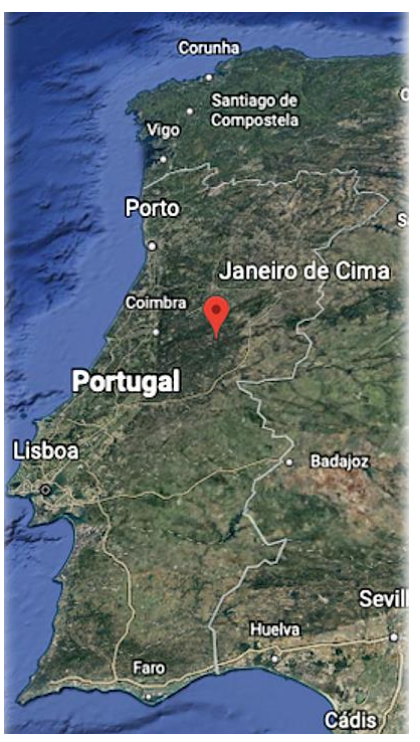

Fig 3. Location of Janeiro de Cima. Source: Google Earth [accessed 6-4-2021]

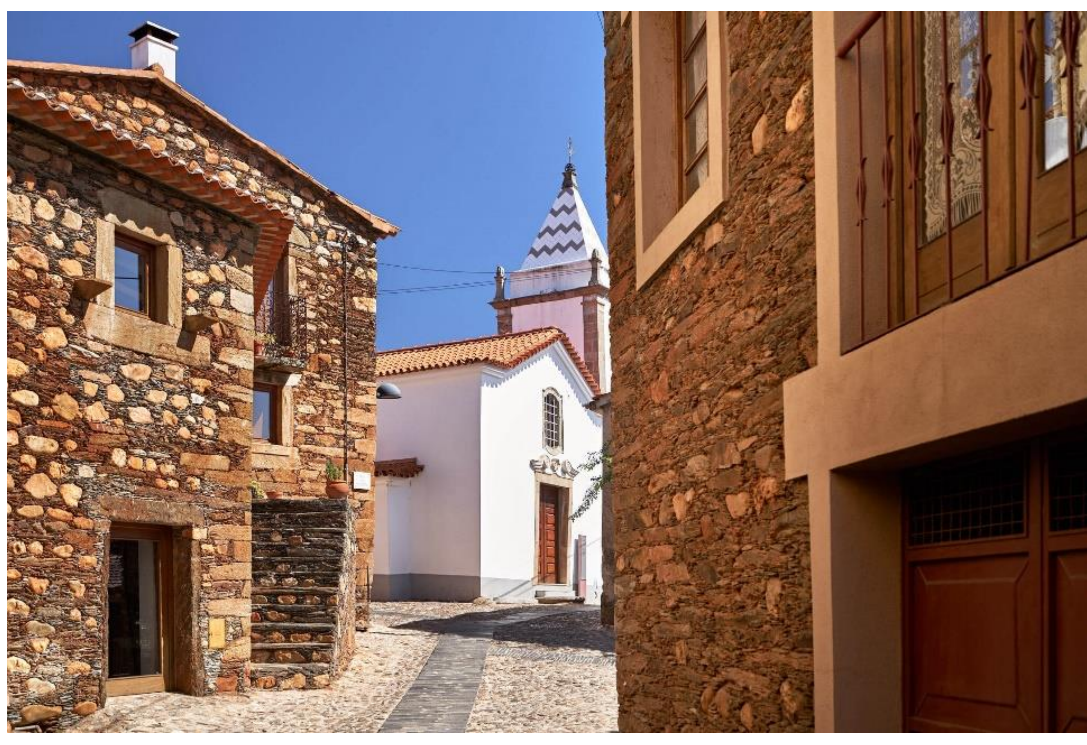

Fig 4. Janeiro de Cima. Aldeias do Xisto.

In order to assess the role of nostalgia and sensorial experiences in the purchase of local products, visitor data collected within a major, three-year research project, namely from the hinterland village of Janeiro de Cima (see Figure 3), was used, given that here, local products present one of the village's attractions. Janeiro de Cima has around 352 inhabitants and is part of the municipality of Fundão, in the Central Region of Portugal. It is located close to two towns of the region's interior - Fundão and Castelo-Branco - and next to the river Zêzere, in the Serra da Gardunha mountains, not far from the natural park of Serra da Estrela. The village is known as a unique 'schist village', with particularly interesting architecture due to a mixture of schist and rolled river stones, which can be seen in houses' façades and pavements. It has been part of the nationally renowned 'Network of Schist Villages' since 2001. This network of 27 villages, developed with support from EU funds, yields sustainable village development, based on restoring bringing value to traditional schist-stone architecture, traditions, handicraft and local products (see http://www.aldeiasdoxisto.pt). It also includes the strategic use of these resources 
in sustainable nature, cultural and rural tourism, empowering village actors through a democratic, network governance approach in creating development strategies in scarcely inhabited rural areas of the country's interior, which face depopulation and lack economic alternatives to smallscale, unprofitable agriculture. Public investments in restoration, stimulation of local craft activities and a network governance structures permitted development that was both top-down, assisted by regional entities and municipalities, and bottom-up, involving local actors. The network governance structure, led by the non-profit private association ADXISTUR, with full-time technical staff, enables ongoing work in fields such as training, joint promotion and selling, digital marketing and development of events, projects and products. One focus is on exploring 'local products, handicraft or agri-food products, which are seen as authentic, originally related with everyday life, containing traditional knowledge that is seen as a valuable and unique cultural dimension' (Lane et al, 2013: 68). These products are sold in the schist village stores thereby reducing one key problem - the producer's micro scale and the lack of access to large distribution channels. It is a means of yielding reasonable economic return of an otherwise not profitable activity helping residents both in maintaining traditions and staying in the villages. The network's 12 stores, located both in the villages and in cities like Lisbon, Coimbra and even Barcelona, sell food, publications and handicraft, sometimes combining traditional craft with modern design or presented with innovative packaging (Lane et al, 2013; http://www.aldeiasdoxisto.pt).

The schist village attracts an interesting number of people on weekends and in the high season because of its beautiful restoration, its good location, trails available to discover the territory, a few tourism facilities (two small accommodation units, a café/bar and a restaurant) and the river beach, especially appealing in the hot summer, apart from residential tourism. An important attraction of this village, particularly for the present study, is the Weavers' House. This is an institution which aims at bringing value to the region's linen craft, both through workshops directed at residents interested in keeping up this artistic skill, and through expositions directed at visitors. Apart from beautiful linen craft examples, it presents the history and role of this handicraft for the region. Visitors may even try to weave on a loom and finally purchase pieces of linen handicraft in the small store, which also presents other local products (such as marmalade, honey or liquors, as well as handicraft) from other schist villages. Additionally, there is a local shop that also sells a variety of local food products (e.g., regional cherry, chestnut, cheese, sausages, olive oil, bread).

Janeiro de Cima mirrors the sociodemographic reality of many small villages of the country's hinterland: villages that are losing population, with a high level of ageing and correspondingly facing limited economic opportunities, while small-scale agriculture is still present, mainly as complementary activity and for family support.

There is no official record of visitor flows, but the village's tourist appeal is revealed by the fact that, according the parish president, the number of persons living in the village at weekends and in the high season more than doubles, mainly due to several second homes in Janeiro de Cima.

\subsection{Sampling}

To validate the model, data from a survey conducted among the visitors of Janeiro de Cima was used. The sample selected employs a cluster sampling approach, defined in space and time. Concretely, certain sites, such as the Weaver's House, restaurant, café, shop or accommodation units were used for administrating the questionnaire. Researchers administrated it directly on randomly selected days, considering all weekdays in all months of one year, from December 2011 to December 2012, to all village visitors who happened to be present at those sites, yielding response rates between $70 \%$ and $85 \%$ (valid responses against the number of visitors addressed). Considering the small size of the village, where tourists stand out, and thanks to the generous assistance of residents in localizing village visitors, the authors trust that the 265 responses reveal a reasonably sound approximation to the real universe of village visitors during that year. 


\subsection{Measures}

The questionnaire includes questions on respondents' socioeconomic profile, reasons for visiting the village, travel behaviour and the tourist experience. Regarding travel behaviour, respondents reported: whether the village was their main destination or not; the type of accommodation used; the composition of the travel group and group size; daily expenditures made per group and length of stay. Respondents were also asked to indicate, with a Likert-type scale (from 1 "strongly disagree" to 7 "strongly agree"), their feelings of nostalgia evoked by the immersion in the destination culture, the community and their way of living. The items related to nostalgia were developed based on previous research on personal and cultural nostalgia (Holak, Matveev \& Havlena, 2007, Holak \& Havlena, 1998, Holbrook \& Schindler, 2003; Kessous, 2015; Phau et al., 2015). Personal nostalgia is directly and strongly linked to an individual's own and idealized past ("This rural destination reminds me of my roots" and "This rural destination makes me feel nostalgic"), while historical nostalgia involves external sources and narratives that cover the collective past, beyond an individual's personal experience, and act as triggers of the nostalgic emotion ("This rural destination evokes special memories from other times").

\subsection{Data analysis}

Frequencies, percentages, mean values, standard deviations, medians and modes were calculated to describe the overall sample profile and main behavioural and attitudinal variables, depending upon the type of variable at stake.

To assess the psychometric properties of the model's latent variables (nostalgia and sensory experience), Cronbach's alpha was calculated using the IBM SPSS Statistics 24 program and a confirmatory factor analysis was performed using the IBM AMOS 24.0 program. To test the suggested model, we conducted mediation and moderation analyses based on Ordinary Least Squares (OLS) regression (model 1), using the package PROCESS for SPSS, version 2.16.2.

\section{Results}

\subsection{Sample profile}

As Table 1 shows, the sample is made up of 265 tourists, aged between 18 and 79 years, with an average age of around 40 years (SD =14.44). The percentage of women is slightly higher $(54.2 \%)$ than that of men. The majority of visitors to the village are Portuguese $(86.8 \%)$, with those of foreign origin (France and Switzerland) being less relevant. The interviewees come mainly from urban environments $(84.0 \%)$ and the majority have a net monthly family income, either between $€ 1,000$ and $€ 2,000$ (41.1\%), or between $€ 2,000$ and 4,000 (24.2\%).

The main reasons to visit Janeiro de Cima, named in an open-ended question, were its festivities $(\mathrm{N}=51)$, the personal link they have with the village (43), visiting friends and relatives (34), the river (21), the fact that it is a schist village (16), the attempt to escape from stress (13), or the village's architecture (11). Less important motivations mentioned are the rural character of the destination, its nature or the fact that the visit is part of an organized trip (six referrals respectively).

Visitors to Janeiro de Cima (see Table 1) usually stay in hotels, with friends or relatives or engage in camping. Five per cent have a second residence in this village. Most respondents report it being their first visit to the village (70\%). One in five respondents had already been once or twice before and 10 per cent had been to the village three or more times. 
Tab 1. Sample profile and travel behaviour.

\begin{tabular}{|c|c|c|c|c|c|c|}
\hline \multirow{2}{*}{$\begin{array}{l}\text { Sociodemographics } \\
\text { Gender }\end{array}$} & \multirow{2}{*}{\multicolumn{3}{|c|}{ Frequency }} & & & \\
\hline & & & & \multicolumn{3}{|l|}{ Percentage } \\
\hline Male & \multicolumn{3}{|l|}{121} & \multicolumn{3}{|c|}{45.8} \\
\hline Female & \multicolumn{3}{|l|}{143} & \multicolumn{3}{|l|}{54.2} \\
\hline Total & \multicolumn{3}{|l|}{264} & \multicolumn{3}{|l|}{100.0} \\
\hline Place of residence & \multicolumn{3}{|l|}{ Frequency } & \multicolumn{3}{|c|}{ Percentage } \\
\hline Portugal & \multicolumn{3}{|l|}{224} & \multicolumn{3}{|l|}{86.8} \\
\hline France & \multicolumn{3}{|l|}{30} & \multicolumn{3}{|l|}{11.6} \\
\hline Switzerland & \multicolumn{3}{|l|}{4} & \multicolumn{3}{|l|}{1.6} \\
\hline Total & \multicolumn{3}{|l|}{258} & \multicolumn{3}{|l|}{100.0} \\
\hline Net monthly family income & \multicolumn{3}{|l|}{ Frequency } & \multicolumn{3}{|c|}{ Percentage } \\
\hline Up to 500 & \multicolumn{3}{|l|}{15} & \multicolumn{3}{|l|}{6.4} \\
\hline From 501 to 1,000 & \multicolumn{3}{|l|}{55} & 23.3 & & \\
\hline From 1,001 to 2,000 & 97 & & & 41.1 & & \\
\hline From 2,001 to 4,000 & 57 & & & 24.2 & & \\
\hline From 4,001 to 6,000 & 9 & & & 3.8 & & \\
\hline Above 6,000 & 3 & & & 1.3 & & \\
\hline Total & 236 & & & 100.0 & & \\
\hline & Minimum & Maximum & Average & $\begin{array}{l}\text { Standard } \\
\text { Deviation }\end{array}$ & Mode & Median \\
\hline Age & 18 & 79 & 39.74 & 14.44 & 30 & 37 \\
\hline Travel behaviour & & & & & & \\
\hline Type of accommodation & Frequenc & & & Percentag & & \\
\hline Hotel or similar & 76 & & & 38.8 & & \\
\hline With friends/family & 55 & & & 28.1 & & \\
\hline Camping/caravan & 54 & & & 27.6 & & \\
\hline 2nd residence (own house) & 9 & & & 4.6 & & \\
\hline Other & 2 & & & 1.0 & & \\
\hline Total & 196 & & & 100.0 & & \\
\hline No. of previous visits & Frequenc & & & Percentag & & \\
\hline Never & 115 & & & 70.6 & & \\
\hline $1-2$ times & 32 & & & 19.7 & & \\
\hline 3 or more & 16 & & & 9.8 & & \\
\hline Total & 163 & & & 100.0 & & \\
\hline $\begin{array}{l}\text { Characterization of the } \\
\text { visit }\end{array}$ & Frequenc] & & & Percentag & & \\
\hline Main destination & 172 & & & 65.2 & & \\
\hline $\begin{array}{l}\text { Important, but not main } \\
\text { destination }\end{array}$ & 69 & & & 26.1 & & \\
\hline Transit destination & 23 & & & 8.7 & & \\
\hline Total & 196 & & & 100.0 & & \\
\hline Variables & Minimum & Maximum & Average & $\begin{array}{l}\text { Standard } \\
\text { deviation }\end{array}$ & Mode & Median \\
\hline $\begin{array}{l}\text { Number of people in the } \\
\text { travel group }\end{array}$ & 1 & 60 & 6.69 & 10.82 & 2 & 4 \\
\hline $\begin{array}{l}\text { Expenditure/day: } \\
\text { - on accommodation }\end{array}$ & 0 & 300 & 26.86 & 53.08 & 0 & 0 \\
\hline $\begin{array}{l}\text { - on local products/ } \\
\text { souvenirs }\end{array}$ & 0 & 500 & 19.43 & 47.97 & 0 & 10 \\
\hline - on food & 0 & 400 & 39.82 & 57.96 & 0 & 20 \\
\hline
\end{tabular}

Janeiro de Cima is the main destination for two out of three tourists surveyed and a major destination for a quarter. Tourists are part of a very diverse group size, from individuals travelling alone to groups of 60 people, with couples being the most common group (mode $=2$ ). The average group size is 6.67. The average expenditure on accommodation, local products/souvenirs and food is $€ 26.86, € 19.43$ and $€ 39.82$ respectively. It is surprising to observe that the most common expenditure on these items, as shown by the mode of the variables, is zero euros; however, all expenses, including purchase of local products, reveal a significant dispersion. 
Tab 2. Descriptors for model variables.

\begin{tabular}{|c|c|c|}
\hline Variables & Average & $\begin{array}{l}\text { Standard } \\
\text { deviation }\end{array}$ \\
\hline \multicolumn{3}{|l|}{ Nostalgia } \\
\hline This rural destination reminds me of my roots & 4.89 & 2.23 \\
\hline This rural destination makes me feel nostalgic & 4.65 & 2.07 \\
\hline This rural destination evokes special memories from other times & 5.00 & 2.13 \\
\hline \multicolumn{3}{|l|}{ Sensorial experience } \\
\hline $\begin{array}{l}\text { This experience has been rich in images and colours (e.g., landscapes, rural } \\
\text { architecture). }\end{array}$ & 6.14 & 1.00 \\
\hline This experience has been rich in sounds (e.g., birds, church bells). & 5.88 & 1.49 \\
\hline This experience has been rich in smells (e.g., countryside, food, nature). & 5.82 & 1.43 \\
\hline $\begin{array}{l}\text { This experience has been rich in tactile sensations (e.g., texture of handicraft, of } \\
\text { plants). }\end{array}$ & 4.72 & 1.90 \\
\hline $\begin{array}{l}\text { Purchase of local products (I have bought local products, as authentic and typical } \\
\text { of the region.) }\end{array}$ & 4.52 & 2.14 \\
\hline \multicolumn{3}{|l|}{ Trying local food } \\
\hline I have tasted local food. & 4.76 & 2.06 \\
\hline
\end{tabular}

With respect to the variables in the model, the average scores are above four (on a seven-point scale) for nostalgia, sensory experiences (these being relatively more intense), purchase of local products, and trying local food, with some deviation from the mean revealing the dispersion of reported experience evaluations within the sample. Perceptions of the indicators are particularly high for "this experience has been rich in images and colours (e.g., landscapes, rural architecture)" (mean $=6.14, \mathrm{SD}=1.00$ ), "this experience has been rich in sounds (e.g., birds, church bells)" (mean $=5.88, \mathrm{SD}=1.49$ ) and "this experience has been rich in smells (e.g., countryside, food, nature) (mean $=5.82, \mathrm{SD}=1.43$ ).

\subsection{Reliability and validity}

The analysis of reliability of the scales is performed using three measures: Cronbach's a, composite reliability and extracted variance. The first of these measures is calculated using the IBM SPSS 24.0 and the last two from a confirmatory factorial analysis using the IBM AMOS 24.0 program. Confirmatory factor analysis (maximum likelihood estimation) showed good fit of the data $(X 2=15.850 ; \mathrm{df}=13 ; \mathrm{X} 2 / \mathrm{df}=1.219 ; \mathrm{p}=0.257 ; \mathrm{RMSEA}=0.036 ; \mathrm{TLI}=0.984 ; \mathrm{CFI}=$ 0.990; IFI = 0.990).

The values for the three reliability measures (see Table 3) generally exceed the thresholds recommended in the literature (Hair et al., 2014), and show the reliability of the measurement scales, although the variance extracted for the sensorial experience variable $(E V$ sensorial Experience $=$ 0.325 ) is lower than the level recommended in the literature (0.5). In any case, as these authors point out, "the reliability of the summated scales is best measured by Cronbach's alpha" (p. 145) which in both cases exceeds the value recommended for an exploratory study (0.6), being, in the case of sensorial experience, close to the general threshold of 0.7 .

Tab 3. Measures of reliability.

\begin{tabular}{|l|c|c|c|}
\hline Scales & Cronbach's $\boldsymbol{\alpha}$ & Composite reliability & Extracted variance \\
\hline Nostalgia & 0.80 & 0.81 & 0.60 \\
\hline Sensorial experience & 0.69 & 0.66 & 0.33 \\
\hline
\end{tabular}

The discriminant validity analysis, based on a confirmatory factorial analysis, relies on two criteria. On the one hand, following the criterion of the extracted variance, it is observed that these values $\left(E V_{\text {Sensorial Experience }}=0.33 ; E V_{\text {Nostalgia }}=0.60\right)$ are higher than the square of the covariance between factors (0.16); on the other hand, following the criterion of the confidence interval, it was found that the confidence interval for the covariance between the two variables excludes the unit (Fornell \& Larcker, 1981). These results demonstrate the existence of discriminant validity (see Table 4). 
Tab 4. Discriminant validity.

\begin{tabular}{|l|l|l|}
\hline & Nostalgia & Sensorial experience \\
\hline Nostalgia & 0.60 & 0.17 \\
\hline Sensorial experience & $(0.16,0.64)$ & 0.32 \\
\hline
\end{tabular}

Note: Confidence intervals for the covariance $+/-2$ errors below, average variance extracted in the diagonal, and squared covariance above.

The results included in Table 5 support the convergent validity of the measurement scales. All indicators load significantly and substantially on their corresponding factors, with loads greater than 0.5, which is the recommended threshold (Hair et al., 2014).

Tab 5. Convergent validity.

\begin{tabular}{|l|l|l|l|l|}
\hline Constructs and indicators & Estimates & $\begin{array}{l}\text { Standard } \\
\text { error }\end{array}$ & $\begin{array}{l}\text { Critical } \\
\text { ratio }\end{array}$ & $\begin{array}{l}\text { Standardized } \\
\text { estimates }\end{array}$ \\
\hline Nostalgia & & & & \\
\hline This rural destination reminds me of my roots & 1.00 & & & 0.79 \\
\hline This rural destination makes me feel nostalgic & 0.70 & 0.09 & 7.84 & 0.61 \\
\hline $\begin{array}{l}\text { This rural destination evokes special memories } \\
\text { from other times }\end{array}$ & 1.08 & 0.12 & 9.21 & 0.89 \\
\hline Sensorial experience & & & & \\
\hline $\begin{array}{l}\text { This experience has been rich in images and } \\
\text { colours (e.g., landscapes, rural architecture). }\end{array}$ & 1.00 & & & 0.53 \\
\hline $\begin{array}{l}\text { This experience has been rich in sounds (e.g.: } \\
\text { birds, church bells). }\end{array}$ & 1.69 & 0.36 & 4.69 & 0.61 \\
\hline $\begin{array}{l}\text { This experience has been rich in smells (e.g., } \\
\text { countryside, food, nature). }\end{array}$ & 1.59 & 0.34 & 4.65 & 0.60 \\
\hline $\begin{array}{l}\text { This experience has been rich in tactile } \\
\text { sensations (e.g., texture of handicraft, of } \\
\text { plants...). }\end{array}$ & 1.88 & 0.42 & 4.41 & 0.53 \\
\hline
\end{tabular}

After demonstration of the psychometric properties of the measurement scales, summated scales are obtained for each factor analysed as the average of all indicators. Summated scales are "recommended as the first choice as a remedy for measurement error where possible" (Hair et al., 2014: 273). These composite variables are then used to test the hypothesis of the study.

\subsection{Mediation and moderation effects}

To test the mediation effects of nostalgia on the purchase of local products through sensorial experience, we performed a mediation analysis based on Ordinary Least Squares (OLS) regression (model 1), using the package PROCESS for SPSS, version 2.16.2. To test the moderation effect of the type of visitor, we conducted a conditional process analysis (model 2), combining both mediation and moderation in the same analysis. In both cases, we follow the methodology proposed by Hayes (2013), who suggests, "we know that we better understand some phenomenon when we can answer not only whether $X$ affects $Y$, but also how $X$ exerts its effect on $Y$, and when $X$ affects $Y$ and when it does not. The "how" question relates to the underlying psychological, cognitive, or biological process that causally links $X$ to $Y$, whereas the "when" question pertains to the boundary conditions of the causal association" (p. 6). We also consider four control variables: trying local food, age, gender and length of stay.

The mediation analysis (see Table 6 , model 1) shows a positive and significant relationship between nostalgia and the sensorial experience $(b=0.16, p<.01)$ and this variable, in turn, is strongly related to the purchase of local products by visitors $(b=0.93, p<.01)$. Table 7 (see model 1) includes total, direct and indirect effects of nostalgia, including bias-corrected bootstrap confidence intervals for the indirect effect. We can conclude that this effect is different from zero as the confidence interval does not include the zero value. Nevertheless, the direct effect is not significant $(b=0.08, p=.33)$. 
In summary, our results indicate that nostalgia impacts on the purchase of local products indirectly through sensorial experience, but not directly. Regarding the effects of the control variables, results indicate that only trying local food is a significant antecedent of the purchase of local products, both direct and indirectly through sensorial experience.

To test the moderating effects of the type of visitor, a conditional process analysis was proposed, following the methodology developed by Hayes (2013). The moderator is a dichotomous variable that reflects if the visitor is an excursionist or a tourist. The analysis reveals that the type of visitor moderates the effect of sensorial experience on the purchase of local products $(b=-2.13, p<.01$, see Table 6, model 2), showing that this effect is stronger if the visitor is a tourist, when compared to an excursionist.

Tab 6. Model coefficients for the mediation and conditional process analysis.

\begin{tabular}{|c|c|c|c|c|c|c|c|c|c|c|c|c|}
\hline & \multicolumn{6}{|c|}{$\begin{array}{c}\text { Model 1. Mediation analysis } \\
\text { Nostalgia } \rightarrow \text { Sensorial experience } \rightarrow \text { Purchase } \\
\text { local products }\end{array}$} & \multicolumn{6}{|c|}{$\begin{array}{c}\text { Model 2. Conditional process analysis } \\
\text { Nostalgia } \rightarrow \text { Sensorial experience } \rightarrow \\
\text { Purchase local products moderated by the } \\
\text { type of visitor (excursionist) }\end{array}$} \\
\hline & \multicolumn{6}{|c|}{ Consequence } & \multicolumn{6}{|c|}{ Consequence } \\
\hline \multirow[t]{2}{*}{ Antecedent } & \multicolumn{3}{|c|}{ Sensorial experience } & \multicolumn{3}{|c|}{$\begin{array}{c}\text { Purchase local } \\
\text { products }\end{array}$} & \multicolumn{3}{|c|}{ Sensorial experience } & \multicolumn{3}{|c|}{$\begin{array}{l}\text { Purchase local } \\
\text { products }\end{array}$} \\
\hline & Coeff. & SE & $\mathbf{p}$ & Coeff. & SE & $\mathbf{p}$ & Coeff. & SE & $\mathbf{P}$ & Coeff. & SE & $\mathbf{p}$ \\
\hline Constant & 4.34 & 0.28 & $<.01$ & -2.97 & 0.73 & $<.01$ & -0.54 & 0.27 & .05 & 2.35 & 0.45 & $<.01$ \\
\hline Nostalgia & 0.16 & 0.04 & $<.01$ & 0.08 & 0.08 & .30 & 0.16 & 0.04 & $<.01$ & 0.12 & 0.08 & .11 \\
\hline $\begin{array}{l}\text { Sensorial } \\
\text { experience }\end{array}$ & --- & $\begin{array}{ll}-- \\
\end{array}$ & --- & 0.93 & 0.11 & $<.01$ & --- & --- & --- & 0.74 & 0.13 & $<.01$ \\
\hline Try local food & 0.14 & 0.04 & $<.01$ & 0.18 & 0.07 & $<.01$ & 0.14 & 0.04 & $<.01$ & 0.17 & 0.07 & .01 \\
\hline Age & -0.01 & 0.01 & .21 & 0.02 & 0.01 & .01 & -0.01 & 0.01 & .36 & 0.03 & 0.01 & $<.01$ \\
\hline Gender & 0.20 & 0.15 & .18 & 0.08 & 0.25 & .76 & 0.22 & 0.15 & .15 & 0.05 & 0.24 & .24 \\
\hline Type of visitor & --- & $\begin{array}{ll}-- \\
\end{array}$ & --- & --- & --- & --- & -0.26 & 0.24 & .27 & -1.53 & 0.43 & $<.01$ \\
\hline $\begin{array}{l}\text { Nostalgia X type } \\
\text { of visitor }\end{array}$ & --- & $\begin{array}{l}-- \\
\end{array}$ & --- & --- & --- & --- & 0.12 & 0.14 & .39 & 0.45 & 0.28 & .11 \\
\hline \multirow{2}{*}{$\begin{array}{l}\text { Sensorial } \\
\text { experience } X \text { type } \\
\text { of visitor }\end{array}$} & --- & --- & --- & --- & --- & --- & --- & --- & --- & -2.13 & 0.59 & $<.01$ \\
\hline & \multicolumn{3}{|c|}{$\begin{array}{c}R^{2}=0.20 ; F(4,174)= \\
10.83, p<.01\end{array}$} & \multicolumn{3}{|c|}{$\begin{array}{c}R^{2}=0.41 ; F(5,173)= \\
24.08, p<.01\end{array}$} & \multicolumn{3}{|c|}{$\begin{array}{c}\left.R^{2}=0.21 ; F(6,172)\right)= \\
7.55, p<.01\end{array}$} & \multicolumn{3}{|c|}{$\begin{array}{c}R^{2}=0.47 ; F(8,170)= \\
18.69, p<.01\end{array}$} \\
\hline
\end{tabular}

Note: Coeff. $=$ coefficient SE $=$ standard error $p=$ level of significance.

Table 7 shows the total effects of the nostalgia variable on the purchase of local products, the direct effects (which occur independently of the sensory experience) and the indirect effects (through this sensory mechanism).

In model 1, these effects are estimated for the entire sample. Results show that a positive effect of nostalgia on the purchase of local products is obtained for all respondents, but only the indirect effect is significant through the sensory experience (effect $=0.15, \mathrm{BootLLCl}=0.06, \mathrm{BootULCl}=$ 0.25 ) and not the direct effect (effect $=0.08, p=0.33, \mathrm{LLCl}=-0.08, \mathrm{ULCl}=0.23$ ). The confidence interval for the direct effect, moreover, includes the value zero, so it cannot be ruled out that this effect is zero; conversely, the confidence interval for the indirect effect, calculated using bootstrap bias-corrected confidence intervals and 5,000 subsamples, does not include the value zero, so it can be ruled out that the indirect effect is zero.

In addition, the analyses carried out in model 2 (Table 7) allow us to assess the importance of considering the type of visitor when testing the model. For the group of excursionists, neither the direct effect of nostalgia on the purchase of local products (effect $=0.52, p=0.06, \mathrm{LLCl}=$ $-0.02, \mathrm{ULCl}=1.05)$ nor the indirect effect through the sensory experience are significant (effect $=-0.31, \mathrm{p}=0.27, \mathrm{BootLLCl}=-1.12$, BootULCl $=0.03$ ); furthermore, the confidence intervals include the value 0 , so it cannot be rejected that these effects are null. On the contrary, for the group of tourists, although nostalgia does not directly impact on the purchase of local products (effect $=0.07, p=0.39, \mathrm{LLCl}=-0.09, \mathrm{ULCl}=0.22$ ), it does through the sensory experience (effect 
$=0.15, p=0.05$, BootLLCI $=0.05$, BootULCI $=0.26$ ), with the confidence interval being entirely above the value 0 , which further supports that this effect is positive.

Tab 7. Direct and indirect effects of nostalgia on the purchase of local products.

\begin{tabular}{|c|c|c|c|c|c|c|}
\hline & \multicolumn{5}{|c|}{$\begin{array}{c}\text { Model 1. Mediation analysis } \\
\text { Nostalgia } \rightarrow \text { Sensorial experience } \rightarrow \text { Purchase local } \\
\text { products }\end{array}$} & \\
\hline & Effect & SE & p & LLCI & ULCI & \\
\hline Total effects & 0.23 & 0.09 & .01 & 0.06 & 0.39 & \\
\hline \multirow[t]{2}{*}{ Direct effects } & 0.08 & 0.08 & .33 & -0.08 & 0.23 & \\
\hline & Effect & \begin{tabular}{|l|} 
BootSE \\
\end{tabular} & & BootLLCI & BootULCI & \\
\hline \multirow[t]{3}{*}{ Indirect effects } & 0.15 & 0.05 & & 0.06 & 0.25 & \\
\hline & \multicolumn{5}{|c|}{$\begin{array}{c}\text { Model } 2 \text {. Conditional process analysis } \\
\text { Nostalgia } \rightarrow \text { Sensorial experience } \rightarrow \text { Purchase local } \\
\text { products moderated by the type of visitor (excursionist) }\end{array}$} & $\begin{array}{c}\text { Moderation } \\
\text { effects }\end{array}$ \\
\hline & Effect & SE & $\mathbf{P}$ & LLCl & ULCI & \\
\hline \multicolumn{6}{|l|}{ Direct effects } & \multirow{3}{*}{ No } \\
\hline Excursionists & 0.52 & 0.27 & 0.06 & -0.02 & 1.05 & \\
\hline \multirow[t]{2}{*}{ Tourists } & 0.07 & 0.08 & 0.39 & -0.09 & 0.22 & \\
\hline & Effect & BootSE & & BootLLCI & BootULCI & \\
\hline Indirect effects & & & & & & \multirow[t]{3}{*}{ Yes } \\
\hline Excursionists & -0.31 & 0.27 & & -1.12 & 0.03 & \\
\hline Tourists & 0.15 & 0.05 & & 0.05 & 0.26 & \\
\hline
\end{tabular}

Note: $\mathrm{SE}=$ standard error; $p=$ level of significance; $\mathrm{LLCl}=$ lower limit confidence interval; $\mathrm{ULCl}=$ upper limit confidence interval; BootSE = bootstrap standard error; BootLLCI = bootstrap lower limit confidence interval; BootULCI = bootstrap upper limit confidence interval

Therefore, the indirect effects of nostalgia on the purchase of local products through sensory experiences are dependent on visitor type. In brief, nostalgia has a significant effect on the purchase of local products for tourists and the sensory experience helps to transmit that effect. Moreover, this indirect effect of nostalgia, which is produced through the sensorial processes, does not occur in all visitors, but only in tourists.

\section{Conclusion and implications}

Rural tourist experiences are frequently associated with nostalgia, sensory-rich experiences and interest in authentic, local products (Bell, 2006; Carvalho et al., 2016; Christou, Farmaki \& Evangelou, 2018; Kastenholz \& Lima, 2013; Rodrigues, Kastenholz \& Morais, 2012; Vignolles \& Pitchon, 2014), but little is known of the dynamics leading from nostalgic tourist experience, and their conditioning factors, to the purchase of local products. As tourists' spending on local products is central to a destination's economic success and sustainability, generating jobs and income also in other sectors, the conditioning factors of such purchases should be carefully analysed to enable destination planners and managers to eventually increase such spending (Kastenholz, Eusébio \& Carneiro, 2016). This is particularly relevant for rural tourist destinations, especially if they are remote and lack economic alternatives to a declining agriculture (Kastenholz et al., 2014). Here, the sales of local products may additionally be a means of keeping local traditions and enhancing local pride and identity, as also found for Portugal, Italy and Germany (Sidali et al., 2015) or Greece (Skuras, Dimara \& Petrou, 2006). For the tourist, such purchases frequently prolong pleasant experiences through consumption and use of these products at home, through sharing them with meaningful others, making memories tangible and enhancing place attachment (Madaleno et al., 2019; Swanson \& Timothy, 2012). 
The present study shows that nostalgia, a frequently referred to as a driver of rural tourism (Chi et al., 2017; Christou, 2020; Christou et al., 2018; Rodrigues et al., 2012; Rodrigues \& Kastenholz, 2021), triggers more intense sensorial experiences amongst tourists, confirming Christou et al.'s results (2018). Additionally, these sensory-rich nostalgic tourist experiences are found to increase the purchase of local products, with these effects (from nostalgia over sensations to purchase), however, only significant for tourists and not for excursionists. This highlights the role of length of stay and involvement with the place when staying longer, permitting more intense, sensory-rich experiences, which may lead to a stronger wish to intensify such experiences even more, and to prolong and share them through local products purchased at the destination.

Several authors (e.g., Christou et al., 2018; Komppulah, 2014) stress the opportunity of rural tourism entrepreneurs to strategically use nostalgia to enhance their business success, creating emotional links. Particularly, sensorial triggers seem to be suitable to enhance such emotions and add value to the rural tourist experience (Christou et al., 2018). The present study confirms these ideas, revealing their concrete impact with data from a tourist survey. Results clearly show that rural tourists' nostalgia feelings positively impact on the purchase of local products through more intense sensorial experiences. Specifically, when considering all the respondents, a significant indirect effect from nostalgia over sensory experience to product purchase is observed, while direct effects from nostalgia to product purchase are non-significant, revealing the mediating effect of sensory experience. However, this effect is dependent on the type of visitor. It seems to be only significant for tourists and not for excursionists.

In practical terms, the results confirm the role of nostalgia and sensory stimuli in rural tourism for enhancing local culture and economy through the production and sales of local products, while these effects are only visible for tourists and not same-day visitors.

Based on these results, and aiming at sustainable rural development, destinations should try to attract more tourists rather than excursionists, corroborating other studies that have revealed the advantage of such a strategy for more sustainable rural development (Martínez-Roget et al., 2020).

Rural destinations can successfully develop nostalgically marked, sensory-rich experiences in diverse ways. For example, the exhibition of local food and tasting opportunities in local stores can enhance visitors' interest in local products, also using other elements of the store environment (e.g., traditional music, decoration, photos showing traditional way of rural life, smell of local flowers or food products, stimulating nostalgia through the activation of diverse senses). Local markets and fairs, possibly with local producers showing part of the production process, can enhance nostalgic travellers' interest while also presenting an excellent opportunity for sales. Additionally, rural accommodation units can collaborate with local food producers in enhancing their guests' experience with the visited place by offering local food for breakfast or also as a cofinanced local merchandising campaign in the form of gift packages with items like cheese, typical bread, honey, small taster bottles of local liquor or handicraft merchandising articles with the logo of the accommodation unit and/ or the visited village. These items can be given to guests when checking in, together with information on these products, their historical context and where to buy them. The opportunity of visiting the artisans or food producers to observe the production process within the 'authentic', sensory-rich experiencescape, engaging with locals and learning about traditions, would certainly intensify experiences with local products. Even more involving would be the opportunity for active co-creating, with even stronger sensorial engagement, through workshops of handicraft of food production, based upon unique endogenous resources and possibly permitting meaningful interaction with local community (Carvalho et al., 2016). All these initiatives, aiming at appealing and engaging experiences, would make visitors feel nostalgic, become more attached to the visited destination and wish to prolong their experience through the purchase of local products. However, the final impact of such experiences goes beyond the tourists' purchase and personal attachment to the place and its products, since they are also likely to share those experiences and the products (as souvenirs or gifts) with friends and relatives and to also recommend them to others (Adongo, Anuga, \& Dayour, 2015). All these dynamics create a renewed demand of traditional items that otherwise may be condemned to disappear due to fierce, low-cost competition of mass-produced food and other items, and this thereby helps keep local cultures alive, while perpetuating symbols of nostalgic rural tourism demand. 
Especially in peripheral rural areas, such souvenir production and sales may actually help remote communities survive, as stressed by Kauppila, Saarinen \& Leinonen (2009) based on their research in Northern Europe.

Still, questions remain as to how to eventually transform excursionists into longer staying tourists or make them become more engaged with the local culture and immersed in the experiencescape, while enhancing their interest in local products. Those travellers may not feel the same level of nostalgia and perhaps be attracted to other dimensions of rural place experiences, which may deserve additional study. However, our results that having previously tried local food was shown to enhance the relationships found here, suggests the importance of permitting such tasting opportunities both in souvenir/food shops and in other tourism facilities (such as typical restaurants), which may also positively impact part of the excursionists. Additionally, qualitative, more in-depth research about the meaning of rural areas for visitation and consumption practices, particularly questioning the role of nostalgia and sensory experiences in this context, seems to be worthwhile to enhance our understanding of such dynamics. Another important analysis would be a comparison between domestic and international travellers, which here was unfortunately not possible given the small number of foreign visitors in the sample. Last, but not least, similar studies in other destinations may help validate the results found here.

\section{Acknowledgement}

The paper was elaborated within the 3 years' research project ORTE (“The Overall Rural Tourism Experience and sustainable local community development"), financed by the national research board Fundação para a Ciência e Tecnologia [PTDC/CS-GEO/104894/2008] and co-financed by COMPETE, QREN, and FEDER. It yielded a comprehensive, multi-fold and multi-stakeholder analysis of the rural tourist experience in villages of Portugal's hinterland, included in village networks yielding development through heritage conservation and rural tourism. This work was financially supported by the research unit on Governance, Competitiveness and Public Policy $(U I D B / 04058 / 2020)+(U I D P / 04058 / 2020)$, funded by national funds through Fundação para a Ciência e a Tecnologia.

Academic references

[1] Adongo, C. A., Anuga, S. W. \& Dayour, F. (2015). Will they tell others to taste? International tourists' experience of Ghanaian cuisines. Tourism Management Perspectives, 15, 57-64. DOI: 10.1016/j.tmp.2015.03.009.

[2] Agapito, D., Pinto, P. \& Mendes, J. (2017). Tourists' memories, sensory impressions and loyalty: in loco and post visit study in Southwest Portugal. Tourism Management, 58, 108118. DOI: 10.1016/j.tourman.2016.10.015.

[3] Almli, V. L., Verbeke, W., Vanhonacker, F., Næs, T. \& Hersleth, M. (2011). General image and attribute perceptions of traditional food in six European countries. Food Quality and Preference 22, 129-138. DOI: 10.1016/j.foodqual.2010.08.008.

[4] Ballina, F. J., Valdés, L. \& del Valle, E. (2021). Quality marks as an economic consolidation factor for rural tourism. Cuadernos de Gestión, 21(1), 93-101. DOI: 10.5295/cdg.181066fb.

[5] Balogh, P., Békési, D., Gorton, M., Popp, J. \& Lengyel, P. (2016). Consumer willingness to pay for traditional food products. Food Policy, 61, 176-184. DOI: 10.1016/j.foodpol.2016.03.005.

[6] Barros, C. P. \& Machado, L. P. (2010). The length of stay in tourism. Annals of Tourism Research, 37(3), 692-706 DOI: 10.1016/j.annals.2009.12.005.

[7] Bell, D. (2006). Variations on the rural idyll. In Cloke, P., Marsden, T. \& Mooney, P. H., eds., Handbook of Rural Studies (pp. 149-160), London: Sage. 
[8] Bond, C., Thilmany, D. \& Keeling Bond, J. (2008). Understanding consumer interest in product and process-based attributes for fresh produce. Agribusiness 24(2), 231-252. DOI: 10.1002/agr.20157.

[9] Brown, C. (2003). Consumers' preferences for locally produced food: A study in southeast Missouri. American Journal of Alternative Agriculture, 18(4), 213-224. DOI: 10.1079/AJAA200353.

[10] Carvalho, M., Lima, J., Kastenholz, E. \& Sousa, A. J. (2016). Co-Creative Rural Tourism Experiences-Connecting Tourists, Community and Local Resources. In Kastenholz, E., Carneiro, MJ., Eusébio, C. \& Figueiredo, E., eds., Meeting Challenges for rural tourism through co-creation of sustainable tourist experiences (pp. 83-106). Newcastle upon Tyne: Cambridge Scholars Publishing.

[11] Cawley, M. \& Gillmor, D. A. (2008). Integrated rural tourism: Concepts and Practice. Annals of Tourism Research, 35(2), 316-337. DOI: 10.1016/j.annals.2007.07.011.

[12] Chambers, S., Lobb, A., Butler, L., Harvey, K. \& Traill, W. B. (2007). Local, national and imported foods: A qualitative study. Appetite 49, 208-213. DOI: 10.1016/j.appet.2007.02.003.

[13] Chi, N., Xue, B. \& Ren, C. (2017). How to Retain Nostalgia in Rural Tourism. Asian Agricultural Research, 9 (4), 99-100.

[14] Christou, P. (2020).Tourism experiences as the remedy to nostalgia: conceptualizing the nostalgia and tourism nexus, Current Issues in Tourism, 23(5), 612-625. DOI: $10.1080 / 13683500.2018 .1548582$.

[15] Christou, P., Farmaki, A. \& Evangelou, G. (2018). Nurturing Nostalgia? A response from rural tourism stakeholders. Tourism Management. 69, 61. DOI: 10.1016/j.tourman.2018.05.010.

[16] Costanigro, M., Kroll, S., Thilmany, D. \& Bunning, M. (2014). Is it love for local/organic or hate for conventional? Asymmetric effects of information and taste on labels preferences in an experimental auction. Food Quality and Preference 31, 94-105. DOI: 10.1016/j.foodqual.2013.08.008.

[17] Darby, K., Batte, M. T., Erst, S. \& Roe, B. (2008). Decomposing local: A conjoint analysis of locally produces foods. American Journal of Agricultural Economics 90(2), 476-486. DOI: 10.1111/j.1467-8276.2007.01111.x.

[18] Di-Clemente, E., Hernández-Mogollón, J. M. \& Campón-Cerro, A. M. (2019). Tourists' involvement and memorable food-based experiences as new determinants of behavioural intentions towards typical products. Current Issues in Tourism, 23(18), 2319-2332. DOI: 10.1080/13683500.2019.1631265.

[19] Eusébio, C, Carneiro, M. J., Kastenholz, E., Figueiredo, E. \& de Sousa, D. (2017). Who is consuming the countryside? An activity-based segmentation analysis of the domestic rural tourism market in Portugal. Journal of Hospitality and Tourism Management 31, 197-210. DOI: 10.1016/j.jhtm.2016.12.006.

[20] Fairley, S., Gibson, H. \& Lamont, M. (2008). Temporal Manifestations of Nostalgia: Le Tour de France. Annals of Tourism Research 70, 120-130. DOI: 10.1016/j.annals.2017.09.004.

[21] Fernández-Ferrín, P., Calvo-Turrientes, A., Bande, B., Artaraz-Miñón, M. \& Galán-Ladero, M. M. (2018). The valuation and purchase of food products that combine local, regional and traditional features: The influence of consumer ethnocentrism. Food Quality and Preference, 64, 138-147. DOI: 10.1016/j.foodqual.2017.09.015.

[22] Figueiredo, E., Kastenholz, E. \& Lima, J. (2013). Recreating Rurality - Visions of Hosts and Guests in Two Portuguese Villages. In Figueiredo, E., Raschi, A., eds., Fertile Links? Connections between tourism activities, socioeconomic contexts and local development in European Rural Areas (pp. 43-70). Florence: Florence University Press. 
[23] Figueiredo, E. (2009). One rural, two visions - environmental issues and images on rural areas in Portugal. European Countryside 1(1), 9-21. DOI: 10.2478/v10091-011-0001-4.

[24] Fornell, C. \& Larcker, D. F. (1981). Evaluating Structural Equations Models with Unobservable variables and Measurement Error. Journal of Marketing Research 18, 39-50. DOI: $10.1177 \% 2 F 002224378101800104$.

[25] Frisvoll, S., Forbord, M. \& Blekesaune, A. (2016). An empirical investigation of tourists' consumption of local food in rural tourism. Scandinavian Journal of Hospitality and Tourism, 16(1), 76-93. DOI: 10.1080/15022250.2015.1066918.

[26] Fusté-Forné, F. (2020). Developing cheese tourism: A local-based perspective from Valle de Roncal (Navarra, Spain). Journal of Ethnic Foods, 7(1). DOI: 10.1186/s42779-020-00064-2.

[27] Garrod, B., Wornell, R. \& Youell, R. (2006). Re-conceptualising rural resources as countryside capital: the case of rural tourism. Journal of Rural Studies 22(1), 117-128. DOI: 10.1016/j.jrurstud.2005.08.001.

[28] Gokovali, U., Bahar, O. \& Kozak, M. (2007). Determinants of length of stay: A practical use of survival analysis. Tourism Economics 14, 205-222. DOI: 10.1016/j.jrurstud.2005.08.001.

[29] Groves, A. (2005). The local and regional food opportunity [Research Report]. Watford: Institute of Grocery Distribution.

[30] Guerrero, L., Guàrdia, M. D., Xicola, J., Verbeke, W., Vanhonacker, F., Zakowska-Biemans, S., Sajdakowska, M., Sulmont-Rossé, C., Issanchou, S., Contel, M., Scalvedi, M. L., Granli, B. S. \& Hersleth, M. (2009). Consumer-driven definition of traditional food products and innovation in traditional foods. A qualitative cross-cultural study. Appetite, 52(2), 345-354. DOI: 10.1016/j.appet.2008.11.008.

[31] Hair, J. F., Black, W. C., Babin, B. J. \& Anderson, R. E. (2014). Multivariate data analysis. $7^{\text {th }}$ ed. Upper Saddle River: Prentice Hall.

[32] Hand, M. S. \& Martinez, S. (2010). Just what does local mean. Choices, 25(1), 13-18.

[33] Hartman, S., Parra, C. \& Roo, G. (2019). Framing Strategic Storytelling in the Context of Transition Management to Stimulate Tourism Destination Development. Tourism Development, 75, 90-98. DOI: 10.1016/j.tourman.2019.04.014.

[34] Hayes, A. F. (2013). Introduction to mediation, moderation, and conditional process analysis: A regression-based approach. New York: Guilford Press.

[35] Hayes, A. F. (2018). Introduction to mediation, moderation, and conditional process analysis: A regression-based approach. $2^{\text {nd }}$ ed. New York: Guilford publications.

[36] Holak, S. \& Havlena, W. (1998). Feelings, fantasies, and Memories: An examination of the emotional components of nostalgia. Journal of Business Research, 42(3), 217-226. DOI: 10.1016/S0148-2963(97)00119-7.

[37] Holak, S., Matveev, A. \& Havlena, W. (2007). Nostalgia in Post-Socialist Russia: Exploring Applications to Advertising Strategy. Journal of Business Research 60(6), 649-655. DOI: 10.1016/j.jbusres.2006.06.016.

[38] Holbrook, M. (1993). Nostalgia and consumption Preferences: Some emerging patterns of consumer tastes. Journal of Consumer Research 20(2), 245-256. DOI: 10.1086/209346.

[39] Holcomb, R. B., Bendfeldt, E., Lelekacs, J., Velandia, M., Woods, T. A., Goodwin, H. L. \& Rainey, R. L. (2016). A local foods system glossary: A rose by any other name unpublished paper]. Retrieved from http://ageconsearch.umn.edu/handle/230079.

[40] Hu, B. \& Yu, H. (2007). Segmentation by craft selection criteria and shopping involvement. Tourism Management 28(4), 1079-1092. DOI: 10.1016/j.tourman.2006.07.006.

[41] Jarratt, D. \& Gammon, S. (2016). We had the most wonderful times: Seaside nostalgia at a british resort. Tourism Recreation Research, 41, 123-133. DOI: $10.1080 / 02508281.2016 .1147213$. 
[42] Jordana, J. (2000). Traditional foods: challenges facing the European food industry. Food Research International 33(3), 147-152. DOI: 10.1080/02508281.2016.1147213.

[43] Kastenholz, E., Eusébio, C., Carneiro, M. J. \& Figueiredo, E. (2013). Host-Guest relationships in rural tourism - evidence from two Portuguese villages. Anatolia 24(3), 367380. DOI: 10.1080/13032917.2013.769016.

[44] Kastenholz, E. \& Carneiro, M. J. (2016). Rural Tourist Experiences. In Kastenholz, E., Carneiro, MJ., Eusébio, C. \& Figueiredo, E. (Eds). Meeting Challenges for rural tourism through co-creation of sustainable tourist experiences (pp. 21-38) Newcastle upon Tyne: Cambridge Scholars Publishing.

[45] Kastenholz, E. (2004). Management of Demand' as a Tool in Sustainable Tourist Destination Development. Journal of Sustainable Tourism, 12(5), 388-408. DOI: 10.1080/09669580408667246.

[46] Kastenholz, E., Carneiro, M., Marques, C. \& Lima, J. (2012). Understanding and Managing the Rural Tourism Experience. Tourism Management Perspectives, 4, 207-214. DOI: 10.1016/j.tmp.2012.08.009.

[47] Kastenholz, E., Eusébio, C. \& Carneiro, MJ. (2016). Purchase of local products within the rural tourist experience context. Tourism Economics, 22(4), 729-748. DOI: $10.1177 \% 2 F 1354816616654245$.

[48] Kastenholz, E., Marques, C. P. \& Carneiro, M. J. (2020). Place attachment through sensoryrich, emotion-generating place experiences in rural tourism. Journal of Destination Marketing and Management, 17, Art. 100455. DOI: 10.1016/j.jdmm.2020.100455.

[49] Kauppila, P., Saarinen, J. \& Leinonen, R. (2009). Sustainable Tourism Planning and Regional Development in Peripheries: a Nordic view. Scandinavian Joumal of Hospitality and Tourism, 9(4), 424435. DOI: 10.1080/15022250903175274.

[50] Keeling Bond, J., Thilmany, D. \& Bond, C. A. (2006). Direct marketing of fresh produce: Understanding consumer purchasing decisions. Choices, 21 (4), 229-236.

[51] Kessous, A. \& Roux, E. (2008). A semiotic analysis of nostalgia as a connection to the past. Qualitative Market Research 11(2), 192-212. DOI: 10.1108/13522750810864440.

[52] Kim, Y. G., Eves, A. \& Scarles, C. (2009). Building a model of local food consumption on trips and holidays: a grounded theory approach. International Journal of Hospitality Management 28, 423-431. DOI: 10.1016/j.jhm.2008.11.005.

[53] Kim, S. \& Kim, S. (2018). Segmentation of potential film tourists by film nostalgia and preferred film tourism program. Journal of Travel \& Tourism Marketing 35(3), 285-305. DOI: 10.1080/10548408.2017.1284705.

[54] Komppulah, R. (2014). The role of individual entrepreneurs in the development of competitiveness for a rural tourism destination - A case study. Tourism Management, 40, 361-371. DOI: 10.1016/j.tourman.2013.07.007.

[55] La Trobe, H. (2002). Local food, future directions [Research Report]. London: Friends of the Earth.

[56] Laesser, C. \& Crouch, G. I. (2006). Segmenting markets by travel expenditure patterns: the case of international visitors to Australia. Journal of Travel Research, 44(4), 397-406. DOI: $10.1177 \% 2 F 0047287505282952$.

[57] Lane, B. \& Kastenholz, E. (2015). Rural Tourism: the evolution of practice and research approaches - towards a new generation concept? Journal of Sustainable Tourism 28(8-9), 1133-1156. DOI: 10.1080/09669582.2015.1083997.

[58] Lane, B., Weston, R., Davies, N., Kastenholz, E., Lima, J. \& Majewski, J. (2013). Industrial Heritage and Agri/Rural Tourism in Europe: a review of their development, socio-economic systems and future policy issues. Brussels: European Union. 
[59] Lang, M., Stanton, J. \& Qu, Y. (2014). Consumers' evolving definition and expectations for local foods. British Food Journal, 116(11), 1808-1820. DOI: 10.1108/BFJ-03-2014-0117.

[60] Lew, A. A. \& McKercher, B. (2002). Trip Destinations, Gateways and Itineraries: The Example of Hong Kong. Tourism Management 23(6), 609-621. DOI: 10.1016/S02615177(02)00026-2.

[61] Lim, K. H. \& Hu, W. (2016). How local is local? A reflection on Canadian local food labeling policy from consumer preference. Canadian Journal of Agricultural Economics/Revue canadienne d'agroeconomie 64(1), 71-88. DOI: 10.1111/cjag.12062.

[62] Madaleno, A., Eusébio, C. \& Varum, C. (2019). The promotion of local agro-food products through tourism: a segmentation analysis. Current Issues in Tourism 22(86), 643-663. DOI: $10.1080 / 13683500.2017 .1296417$.

[63] Martínez, S., Hand, M., Da Pra, M., Pollack, S., Ralston, K., Smith, T. \& Newman, C. (2010). Local food systems: Concepts, impacts and issues [Economic Research Report No. 67]. Washington: US Department of Agriculture.

[64] Martínez-Roget, F., Moutela, J. A. \& Rodríguez, X. A. (2020). Length of stay and sustainability: Evidence from the schist villages network (SVN) in Portugal. Sustainability, 12(10), Art. 4025. DOI: 10.3390/SU12104025.

[65] Merle, A., Herault-Fournier, C. \& Werle, C. O. (2016). The effects of indication of local geographical origin on food perceptions. Recherche et Applications en Marketing (English Edition) 31(1), 26-42. DOI: 10.1177\%2F2051570715626367.

[66] Onozaka, Y., Nurse, G. \& McFadden, D. T. (2010). Local food consumers: How motivations and perceptions translate to buying behavior. Choices 25(1), 1-6.

[67] Phau, I., Quintal, V., Marchegiani, C. \& Lee, S. (2015). Looking beyond pasta and pizzas: examining personal and historical nostalgia as travel motives. International Journal of Culture, Tourism and Hospitality Research 10(3), 296-309. DOI: 10.1108/IJCTHR-07-20150073.

[68] Ribeiro, M. \& Marques, C. (2002). Rural Tourism and the development of less favoured areas - between rhetoric and practice. International Journal of Tourism Research 4, 211-220. DOI: $10.1002 /$ jtr.377.

[69] Rodrigues, A. \& Kastenholz, E. (2021). Nostalgia. In Buhalis, D., ed., Encyclopedia of Tourism Management and Marketing. Cheltenham: Edward Elgar Publishing. DOI: $10.4337 / 9781800377486$.

[70] Rodrigues, Á., Kastenholz, E. \& Morais, D. (2012). Travel constraints and nostalgia as determinants of cross-Atlantic legacy tourism. In Pechlaner, H., Lee, T. J. \& Bò, G. D., eds., New Minorities and Tourism (pp. 75-92). Bozen: Europäische Akademie Bozen.

[71] Russell, D. (2008). Nostalgic tourism. Journal of Travel \& Tourism Marketing, 25(2), 103116. DOI: $10.1080 / 10548400802402271$.

[72] Santos, G., Ramos, V. \& Rey-Maquieira, J. (2015). Lenght of stay at multiple destinations of tourism trips in Brasil. Journal of Travel Research 54(6), 788-800. DOI: $10.1177 \% 2 F 0047287514532370$.

[73] Saxena, G., Clark, G., Oliver, T. \& Ilbery, B. (2007). Conceptualizing Integrated Rural Tourism. Tourism Geographies, 9(4), 347-370. DOI: 10.1080/14616680701647527.

[74] Sedikides, C., Wildschut, T., Routledge, C., Arndt, J., Hepper, E. G. \& Zhou, X. (2015). Chapter five - to Nostalgize: Mixing memory with affect and desire. Advances in Experimental Social Psychology, 51, 189-273. DOI: 10.1016/bs.aesp.2014.10.001.

[75] Sharpley, R. (2002). Rural tourism and the challenge of tourism diversification: the case of Cyprus. Tourism Management, 23(3), 233-244. DOI: 10.1016/S0261-5177(01)00078-4. 
[76] Sidali, K., Kastenholz, E. \& Bianchi, R. (2015). Food tourism, niche markets and products in rural tourism: combining the intimacy model and the experience economy as a rural development strategy. Journal of Sustainable Tourism 23(8-9), 1179-1197. DOI: 10.1080/09669582.2013.836210.

[77] Silkes, C., Cai, L. \& Letho, X. (2013). Marketing the culinary tourist. Journal of Travel \& Tourism Marketing, 30(4), 335-349. DOI: 10.1080/10548408.2013.784151.

[78] Sims, R. (2009). Food, place and authenticity: local food and the sustainable tourism experience. Journal of Sustainable Tourism,17(3), 321-336. DOI: 10.1080/09669580802359293.

[79] Skuras, D., Dimara, E. \& Petrou, A. (2006). Rural tourism and visitors' expenditures for local food products. Regional Studies 40(7), 769-779. DOI: 10.1080/00343400600660771.

[80] Suhartanto, D., Dean, D., Sosianika, A. \& Suhaeni, T. (2018). Food souvenirs and their influence on tourist satisfaction and behavioural intentions. European Journal of Tourism Research, 18, 133-145.

[81] Swanson, K. \& Timothy, D. (2012). Souvenirs: Icons of meaning, commercialization and commoditization. Tourism Management, 33, 489-499. DOI: 10.1016/j.tourman.2011.10.007.

[82] Thompson, F., Hannam, K. \& Petrie, K. (2012). Producing Ceramic Art Work Through Tourism Research. Annals of Tourism Research. 39(1), 336-360. DOI: 10.1016/j.annals.2011.06.006.

[83] Thrane, C. \& Farstad, E. (2011). Domestic tourism expenditures: The non-linear effects of length of stay and travel party size. Tourism Management 32(1), 46-52. DOI: 10.1016/j.tourman.2009.11.002.

[84] Vaishar, A., Vidovićová, L. \& Figueiredo, E. (2018). Quality of rural life. Editorial. European Countryside, 10(2), 180-190. DOI: 10.2478/euco-2018-0011.

[85] Vanhonacker, F., Verbeke, W., Guerrero, L., Claret, A., Contel, M., Scalvedi, L., ŻakowskaBiemans, S., Gutkowska, K., Sulmont-Rossé, C., Raude, J., Granli, B. S. \& Hersleth, M. (2010). How European consumers define the concept of traditional food: Evidence from survey in six countries. Agribusiness 26(4), 453-476. DOI: 10.1002/agr.20241.

[86] Vignolles, A. \& Pitchon, P. (2014). A taste of nostalgia: Links between nostalgia and food consumption. Qualitative Market Research 17(3), 225-238. DOI: 10.1108/QMR-06-20120027.

[87] Wang, L., Fong, D., Law, R. \& Fang, B. (2018). Length of stay: its determinants and outcomes. Journal of Travel Research 57(4), 472-482. DOI: $10.1177 \% 2 F 0047287517700315$.

[88] Wilkins, H. (2010). Souvenirs: what and why we buy. Journal of Travel Research, 50(3), 239247. DOI: $10.1177 \% 2 F 1096348018807289$.

[89] Xue, L. \& Kernstetter, D. (2019). Rural Tourism and Livelihood change: an emic perspective. Journal of Hospitality \& Tourism Research 43 (3), 416-437. DOI: $10.1177 / 1096348018807289$.

[90] Yagi, C. \& Pearce, P. (2018). European Castles through Japanese Eyes and Minds. European Journal of Tourism Research 19, 5-22.

[91] Yeh, S. (2015). Explore Recent Nostalgia Consumption Studies in Tourism, Leisure and Hospitality Context. International Journal of Asian Tourism Management 6(2), 124-130.

Other sources

[92] Traditional United Europe Food (2006). TRUEFOOD has a new definition of traditional food products (TFPs). TRUEFOOD info, 1(1). Retrieved from http://www.truefood.eu/files/pages/files/d8_3_4_truefood_info_1.pdf. 